\title{
PEMANTAUAN PERAIRAN TELUK LAMONG DENGAN PENGEMBANGAN ALGORITMA TOTAL SUSPENDED SOLID (TSS) DARI DATA CITRA SATELIT MULTITEMPORAL DAN DATA INSITU
}

\author{
Teguh Hariyanto ${ }^{1}$, Haidar Rizqi Krisananda² \\ 1,2Departemen Teknik Geomatika, FTSLK-ITS, Kampus ITS Sukolilo, Surabaya, 60111, Indonesia \\ e-mail : ${ }^{1}$ teguh_hr@geodesy.its.ac.id
}

\begin{abstract}
Abstrak
Perairan Teluk Lamong Surabaya termasuk perairan yang tercemar berat oleh limbah domestik, limbah industri, limbah pertanian, dan limbah tambak. Pencemaran laut merupakan salah satu masalah yang mengancam bumi ini. Kondisi ini menyebabkan terganggunya kelangsungan hidup biota yang ada disekitarnya, seperti pada perikanan, ekosistem pesisir, dan laut (mangrove, padanglamun, terumbu karang) yang berdampak lebih luas terhadap penurunan pendapatan masyarakat pesisir yang menggantungkan hidupnya pada produktivitas hayati di wilayah pesisir dan pantai. TSS (Total Suspended Solid) merupakan salah satu parameter penentu kualitas air. Metode penginderaan jauh dengan citra satelit dapat menjadi solusi untuk melakukan penelitian TSS. Data yang digunakan dalam penelitian ini yaitu data primer berupa data insitu pada tanggal 27 Agustus 2017 dan data sekunder berupa citra satelit Landsat-8 tahun 2014, 2015, 2016, 2017. Metode yang digunakan dalam penelitian ini didasarkan pada pengolahan citra satelit Landsat 8 menggunakan 3 algoritma yaitu, algoritma Budiman, algoritma Parwati, algoritma Laili, kemudian dilihat korelasi linier antara data citra dan insitu menggunakan uji korelasi. Data hasil korelasi terbaik adalah algoritma Budiman dengan nilai koefisien determinasi sebesar 0,853 Hasil pengolahan data didapatkan nilai TSS bervariasi antara 1-472 mg/L. Status mutu air perairan Teluk Lamong Surabaya berdasarkan Keputusan Menteri Lingkungan Hidup No. 115 tahun 2003 pada Pantai Timur Surabaya rata-rata berada pada nilai $0 \leq$ indeks pencemaran $\leq 1$ yang berarti memenuhi baku mutu (kondisi baik).
\end{abstract}

Kata Kunci: Teluk Lamong Surabaya, TSS, Citra Landsat 8, Algoritma, Baku Mutu Air

\begin{abstract}
Teluk Lamong Surabaya include waters that are heavily polluted by domestic waste, industrial waste, agricultural waste, and pond waste. Sea pollution is one of the problems that threatens the earth. This condition causes disruption to the survival of the surrounding biota, such as fisheries, coastal and marine ecosystems (mangroves, meadows, coral reefs) which have a wider impact on the decline in income of coastal communities who depend their lives on biological productivity in coastal areas. TSS (Total Suspended Solid) is one of the parameters determining water quality. The remote sensing method with satellite images can be a solution for conducting TSS research. The data used in this study is primary data in the form of insitu data on August 272017 and secondary data in the form of Landsat-8 satellite imagery in 2014, 2015, 2016, 2017. The method used in this study is based on processing of Landsat 8 satellite imagery using 3 namely algorithm, Budiman algorithm, Parwati algorithm, Laili algorithm, then we will see the linear correlation between image data and insitu using the correlation test. The best correlation result data is the Budiman algorithm with a coefficient of determination of 0.853 . The results of data processing obtained TSS values vary between 1-472 $\mathrm{mg} / \mathrm{L}$. The status of water quality in the Lamong Bay Surabaya is based on the Minister of Environment Decree No. 115 of 2003 on the East Coast of Surabaya averaged $0 \leq$ pollution index $\leq 1$ which meant meeting the quality standards (good condition).
\end{abstract}

Keywords: Teluk Lamong Surabaya, TSS, Landsat 8 image, Algorithm, Water Quality Standards 


\section{PENDAHULUAN}

Perairan Teluk Lamong merupakan teluk yang terletak di antara Pulau Madura dan Jawa. Perairan Teluk Lamong menjadi lokasi penelitian yang menarik, tidak hanya karena adanya pembangunan pelabuhan tetapi lokasi ini juga pernah menjadi kawasan yang diperebutkan oleh Surabaya dan Gresik. Teluk Lamong juga memiliki potensi yang sangta baik untuk dijadikan daerah berkembang. Pada daerah sekitar Teluk Lamong ini, terdapat hutan mangrove dan terdapat sebuah delta tepat didepan mulut sungai didekat Teluk Lamong ini. Pada sisi lain, pembangunan yang dilakukan di sekitar Teluk Lamong diduga dapat memberikan dampak negatif terhadap lingkungan baik dipesisir maupun di laut, khususnya dampak sedimentasi.

Pencemaran laut merupakan salah satu masalah yang mengancam bumi ini. Dilihat dari karakteristrik limbah cair di Jawa Timur, diketahui volume limbah cair tertinggi berasal dari sumber limbah domestik sekitar $84.4 \%$ dari total volume sumber pencemaran (Wijaya \& Kartika, 2004). Hal ini memberikan pengaruh yang merugikan bagi manusia dan lingkungan air. Tingkat pencemaran laut ini telah menjadi ancaman serius bagi laut Indonesia dengan segala potensinya. Komponen-komponen yang menyebabkan pencemaran laut seperti partikel kimia, limbah industri, limbah pertambangan, limbah pertanian dan perumahan, kebisingan, atau penyebaran organisme asing di dalam laut yang berpotensi memberi efek buruk terhadap kestabilan ekosistem perairan Pantai Timur Surabaya. Persoalan air yang paling besar adalah masalah pencemaran air. Pencemaran air adalah suatu perubahan keadaan di suatu tempat penampungan air seperti danau, lautan, dan air tanah akibat aktivitas manusia. Perubahan ini mengakibatkan menurunnya kualitas air hingga ke tingkat yang membahayakan sehingga air tidak bisa digunakan sesuai dengan peruntukannya. Kondisi ini menyebabkan terganggunya kelangsusngan hidup biota yang ada disekitarnya, seperti pada perikanan, ekosistem pesisir, dan laut (mangrove, padanglamun, terumbu karang), yang berdampak lebih luas terhadap penurunan pendapatan masyarakat pesisir yang menggantungkan hidupnya pada produktivitas hayati di wilayah pesisir dan pantai (Saeni, 2008).

Parameter yang dapat digunakan untuk mengukur sedimentasi yaitu TSS (Total Suspended Solid). Metode penginderaan jauh dengan citra satelit dapat menjadi solusi untuk melakukan penelitian masalah sedimentasi, karena metode ini lebih efisien dan efektif dalam penelitian berskala luas. Salah satu citra satelit yang dapat digunakan untuk meneliti masalah TSS adalah Landsat karena memiliki band dengan panjang gelombang yang dapat digunakan untuk mengukur nilai TSS, memiliki resolusi spasial yang baik dan multitemporal.

Karena hal-hal tersebut diatas, maka dirasa perlu untuk melakukan penelitian sedimentasi menggunakan parameter TSS di daerah perairan Teluk Lamong dan sekitarnya menggunakan citra satelit Landsat untuk memberi informasi mengenai nilai sebaran potensi sedimentasi, dan rekomendasi pengelolaan wilayah pesisir di daerah tersebut. Hasil dari penelitian ini diharapkan dapat digunakan dalam rangka optimalisasi hasil penelitian sedimentasi menggunakan teknologi citra satelit dan dapat bermanfaat untuk pengelolaan wilayah pesisir ke depannya.

\section{METODE}

\section{Lokasi penelitian}

Lokasi penelitian mengambil daerah studi wilayah perairan Teluk Lamong, Jawa Timur yang terletak pada $7^{0} 11^{\prime} 13^{\prime \prime}$ LS dan $112^{\circ} 41^{\prime} 24^{\prime \prime}$ BT. Data in situ yang digunakan dalam penelitian ini adalah sampel air yang diambil pada perairan Teluk Lamong Jawa Timur dengan jarak minimal $2 \mathrm{~km}$ dari daratan.

Teluk Lamong, Jawa Timur sebagai lokasi penelitian ini merupakan kawasan yang sedang berkembang dan tempat bermuaranya beberapa sungai/kali yaitu : Kali Lamong, Kali Semeni, Kali Branjangan, Kali Manukan, Kali Krembangan dan Kali Mas

\section{Peralatan dan Data}

Dalam penelitian ini menggunakan data citra satelit Landsat-8 pada kawasan perairan pantai Timur Surabaya yaitu yaitu citra Landsat 8 
tanggal 24 Agustus 2017, 21 Agustus 2016, 19 Agustus 2015, dan 1 September 2014. Data nilai TSS di 20 titik pengamatan di lapangan yang diambil pada tanggal 27 Agustus 2017 digunakan sebagai data untuk melakukan validasi dan analisa nilai TSS citra. Peralatan yang digunakan dalam penelitian ini meliputi perangkat keras, yaitu, laptop, GPS navigasi, perahu motor, botol sampel, alat tulis, dan kamera digital. Adapun perangkat lunak yang digunakan dalam penelitian ini yaitu, Microsoft Office dan Excel 2016, ArcGIS 10.3, dan SNAP.

\section{Tahapan Pengolahan Data}

Adapun langkah-langkah dalam proses pengerjaan penelitian ini yaitu:

1. Melakukan proses koreksi citra. Dalam hal ini ada dua koreksi, yaitu koreksi geometrik dan koreksi radiometrik. Koreksi geometrik yakni pembetulan citra secara geometrii sehingga proyeksi peta dan sistem koordinat yang digunakan sesuai dengan dunia nyata [7]. Selanjutnya, melakukan koreksi radiometrik citra. Koreksi radiometrik meliputi kalibrasi radiometrik dan koreksi atmosfer. Kalibrasi radiometrik yakni melakukan konversi nilai Digital Number pada citra ke nilai reflektan ( $\mathrm{TTOA})$ menggunakan rumus berikut ini:

$$
\rho \lambda=\mathrm{M} \rho * \mathrm{Qcal}+\mathrm{A} \rho
$$

Dimana:

$$
\begin{aligned}
& P \lambda=\text { Nilai reflektan pada band } \\
& \text { ke i (Wm-2 sr-l } \mu m-l) \\
& \mathrm{Mp}=\text { Faktor skala penguji radian } \\
& \text { untuk setiap band } \\
& \text { (RADIANCE_MULT_BAND_ } \\
& \text { n) dari metadata, } n \text { adalah } \\
& \text { nomor band } \\
& A p=\text { Faktor skala penjumlah } \\
& \text { Radian untuk band } \\
& \text { (RADIANCE_ADD_BAND_n } \\
& \text { metadata, dimana } \mathrm{n} \\
& \text { adalah nomor band) } \\
& \text { Qcal = Quantized and calibrated } \\
& \text { standard product pixel } \\
& \text { values (DN) }
\end{aligned}
$$

Citra yang sudah dalam bentuk nilai reflektan kemudian dilakukan proses koreksi atmosfer. Koreksi atmosfer menggunakan metode 6SV (Second Simulation of the Sensor Signal in the Sensor Spectrum-Vector) yang menggunakan parameter berupa tanggal akuisisi citra Landsat 8, model aerosol, model atmosfer, jarak pandang. Parameter ini digunakan untuk mendapatkan nilai $x a, x b, x c^{[8]}$. Berikut ini merupakan persamaan $6 \mathrm{SV}$ :

$$
\begin{aligned}
& y=a x^{*}(L \lambda)-x b \\
& a c r=y /\left(1 .+x c^{*} y\right)
\end{aligned}
$$

$$
\begin{aligned}
\text { Dimana: }= & \text { Reflektan terkoreksi } \\
\text { atmosfer (Atmospheric } & \\
& \text { Corrected Reflectance) } \\
(\lambda)= & \text { Citra berformat radian } \\
x a= & \text { parameter koreksi yang } \\
& \text { diperoleh dari perangkat } \\
& \text { lunak 6SV berbasis web } \\
& \text { yang ada di } \\
& \text { http://6s.Itdri.org/. }
\end{aligned}
$$

2. Pemotongan citra Landsat 8 pada daerah perairan Teluk Lamong Surabaya. Hal ini dilakukan untuk memfokuskan dan memperkecil daerah penelitian pada citra yang akan diolah.

3. Pemisahan darat dan laut. Daerah penelitian utama adalah daerah pesisir dan perairan, sehingga perlu dilakukan pemisahan daerah yang berada diatas air. Proses ini dengan menutup bagian darat dengan nilai 0 sehingga daratan tidak ikut dalam perhitungan algoritma. Proses pemisahan daratan dan lautan dilakukan dengan menggunakan algoritma NDWI (Normalized Difference Water Index). Berikut ini merupakan rumus NDWI:

$$
\mathrm{NDWI}=\frac{\text { band } 3 \text {-band } 5}{\text { band } 3+\text { band } 5}
$$

$$
\begin{aligned}
& \text { Dimana: } \\
& \text { Band 3 } 3 \text { Kanal hijau yang sudah } \\
& \text { terkoreksi atmosfer } \\
& \text { Band 5 } \begin{array}{l}
\text { Kanal inframerah dekat } \\
\text { yang sudah terkoreksi } \\
\text { atmosfer }
\end{array}
\end{aligned}
$$


4. Selanjutnya dilakukan perhitungan TSS menggunakan data citra landsat 8 menggunakan algoritma perhitungan TSS. Data insitu diperoleh dengan melakukan pengambilan sampel air laut secara acak. Air laut yang dijadikan sampel adalah air yang berada pada permukaan $( \pm 50 \mathrm{~cm})$ dari kedalaman laut dengan pengambilan sampel titik berjumlah \pm 30 titik. Pada waktu bersamaan dilakukan pengambilan sampel air, dilakukan juga pengambilan data koordinat titik sampel menggunakan GPS Handheld.

Terdapat 3 Algoritma yang digunakan untuk menentukan nilai TSS (Total Suspended Solid), kemudian untuk hasil algoritma yang paling baik akan digunakan untuk menentukan nilai TSS di kawasan Pantai Timur Surabaya, ketiga algoritma itu adalah:

\section{- Algoritma Budiman}

Perhitungan nilai TSS menggunakan dari penelitian Budiman pada area penelitian Delta Mahakam. Pada algoritma ini menggunakan kanal merah (0,630-0,680 $\mu \mathrm{m})$. Rumus algoritma yang digunakan adalah sebagai berikut:

TSS $=3,3238 * \exp (34,099 *$ Red Band $)$

- Algoritma Laili

Perhitungan nilai TSS

menggunakan algoritma dari

penelitian Laili pada area

penelitian perairan Pulau

Poteran $^{[12]}$. Pada algoritma ini mengunakan kanal hijau $(0,525-$ $0,600 \mu \mathrm{m})$ dan kanal merah (0,630-0,680 $\mu \mathrm{m})$. Rumus algoritma yang digunakan adalah sebagai berikut:

$\mathrm{TSS}=31,42 * \frac{\log (\text { RRS2) }}{\log (\text { RRS4) }}-12,719$

\section{- Algoritma Parwati}

Citra yang diolah menggunakan algoritma ini terdiri dari tahun 2013-2017. Hal ini dilakukan untuk melihat nilai perubahan TSS pada masing-masing titik sampel.

5. Uji Korelasi dilakukan dengan menghubungkan nilai uji sampel dilapangan dengan nilai TSS pada citra sehingga dapat diketahui bentuk hubungannya.

6. Melakukan analisa status mutu air dengan metoda indeks pencemaran berdasarkan nilai TSS merujuk pada Keputusan Menteri Negara Lingkungan Hidup Lingkungan Hidup Nomor 115 Tahun 2003 Tentang Pedoman Penetuan Status Mutu Air. Metode ini menggunakan model Indeks Pencemaran (IP), pada penggunaanya dibutuhkan nilai rata-rata dan nilai maksimal sampel. Untuk mendapatkan nilai tersebut, berikut ini rumus yang digunakan sebagi berikut.

$$
P I=\sqrt{\frac{(\mathrm{X} / \mathrm{Xmax})^{2}+(\mathrm{X} / \mathrm{XRatarata})^{2}}{2}}
$$

$$
\begin{array}{lll}
\text { Dimana: } & \\
X & \text { Nilai TSS pada titik sampel } \\
\text { Xmax } & = & \text { Nilai TSS maksimal sampel } \\
& \text { atmosfer } \\
\text { Xrata-rata }= & \text { Nilai TSS rata-rata sampel }
\end{array}
$$

Tabel 1. Evaluasi terhadap Nilai PI

\begin{tabular}{ll}
\hline Nilai & Keterangan \\
\hline $0 \leq \mathrm{PI} \leq 1$ & Memenuhi baku mutu \\
$1<\mathrm{PI} \leq 5$ & Cemar ringan \\
$5<\mathrm{PI} \leq 10$ & Cemar sedang \\
$\mathrm{PI}>10$ & Cemar berat \\
\hline
\end{tabular}

Berdasarkan nilai PI dapat dilihat nilai kondisi perairan Pantai Timur Surabaya.

\section{HASIL DAN ANALISA}

Perbandingan Nilai TSS Citra 24 Agustus 2017 Menggunakan 3 Algoritma dengan TSS In Situ Perbandingan TSS Citra 24 Agustus 2017 menggunakan Algoritma TSS Parwati, Algoritma TSS Budiman, dan Algoritma TSS Laili dengan TSS In Situ. 
Tabel 2. Nilai Konsentrasi TSS Menggunakan 3 Algoritma Berbeda

\begin{tabular}{cccccc}
\hline No & Lokasi & $\begin{array}{c}\text { TSS } \\
\text { In } \\
\text { Situ } \\
\text { mg/L }\end{array}$ & $\begin{array}{c}\text { Algoritma } \\
\text { Laili mg/L }\end{array}$ & $\begin{array}{c}\text { Algoritma } \\
\text { Budiman } \\
\mathrm{mg} / \mathrm{L}\end{array}$ & $\begin{array}{c}\text { Algoritma } \\
\text { Parwati } \\
\mathrm{mg} / \mathrm{L}\end{array}$ \\
\hline 1 & 001 & 130 & 18,504 & 34,013 & 26,391 \\
2 & 002 & 36 & 16,988 & 24,124 & 14,723 \\
3 & 003 & 52 & 16,621 & 25,529 & 17,655 \\
4 & 004 & 384 & 43,878 & 135,478 & 141,749 \\
5 & 005 & 472 & 53,936 & 166,525 & 174,234 \\
6 & 006 & 200 & 22,854 & 70,561 & 71.266 \\
7 & 007 & 140 & 15,998 & 66,756 & 28,422 \\
8 & 008 & 220 & 25,139 & 77,617 & 78,392 \\
9 & 009 & 280 & 31,996 & 98,786 & 99,771 \\
10 & 010 & 150 & 17,140 & 68,147 & 30,451 \\
11 & 011 & 140 & 15,899 & 66,749 & 28,421 \\
12 & 012 & 150 & 17,098 & 68,210 & 27,993 \\
13 & 013 & 262 & 29,939 & 92,435 & 53,807 \\
14 & 014 & 152 & 18,543 & 69,038 & 30,862 \\
15 & 015 & 180 & 20,569 & 69,759 & 36,548 \\
16 & 016 & 110 & 14,378 & 32,778 & 22,335 \\
17 & 017 & 120 & 15,009 & 33,579 & 24,365 \\
18 & 018 & 210 & 23,997 & 73,324 & 42,335 \\
19 & 019 & 206 & 23,540 & 71,927 & 41,827 \\
20 & 020 & 110 & 14,378 & 32,687 & 22,335 \\
\hline
\end{tabular}

Validasi Hasil Pengolahan Citra dengan Data Lapangan

Uji validasi dilakukan menggunakan data Citra Landsat 8 pada tanggal 24 Agustus 2017 dan pengambilan data insitu pada tanggal 27 Agustus 2017. Pada uji validasi dilakukan perhitungaan korelasi data olahan citra dengan data hasil nilai TSS yang ada di lapangan. Hal ini digunakan untuk melihat sejauh mana kedekatan atau kebaikan data citra yang digunakan. Berikut adalah grafik uji validasi antara data lapangan dengan data citra.

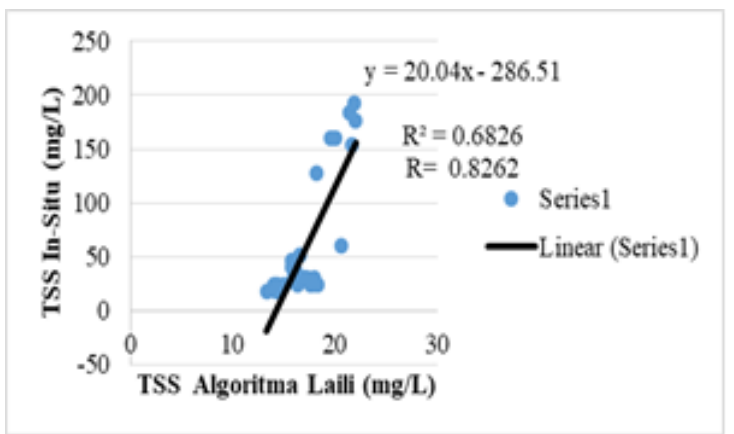

Gambar 1. Uji Korelasi Nilai TSS Algoritma Laili (2015)

Uji korelasi data lapangan TSS dengan data hasil olahan TSS Citra Landsat 8 menggunakan Algoritma Laili (2015) mempunyai nilai koefisien korelasi sebesar $82,6 \%$. Hal ini menjelaskan bahwa ada hubungan antara nilai TSS data citra dengan nilai TSS In Situ kuat.

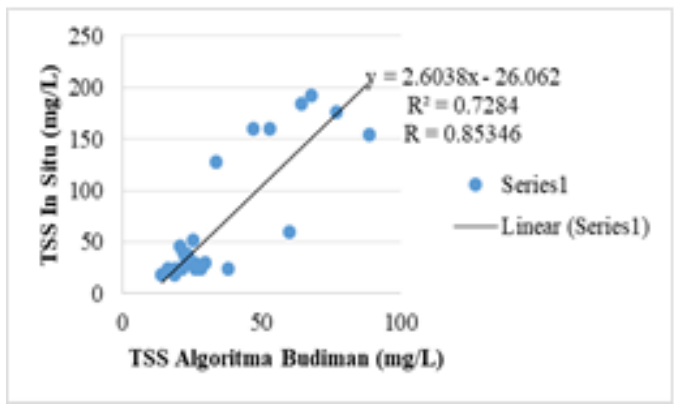

Gambar 2. Uji Korelasi Nilai TSS Syarif Budiman (2004)

Uji korelasi data lapangan TSS (Total Suspended Solid) dengan data hasil olahan TSS (Total Suspended Solid) citra Landsat 8 menggunakan Algoritma Budiman (2004) mempunyai nilai koefisien korelasi sebesar $85,3 \%$. Hal ini menjelaskan bahwa ada hubungan antara nilai TSS data citra dengan nilai TSS data In Situ sangat kuat.

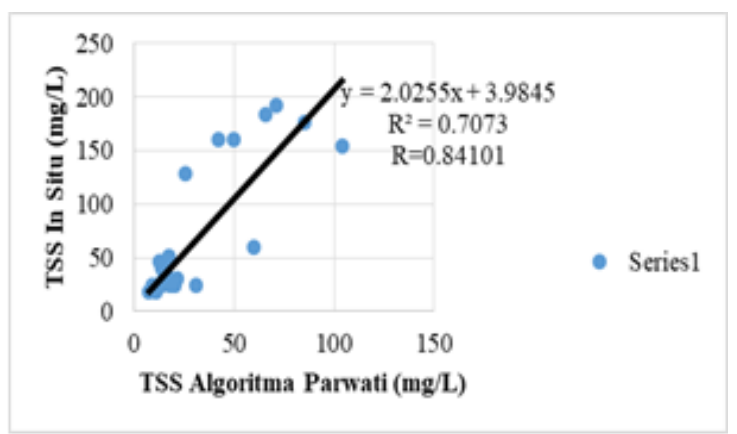

Gambar 3. Uji Korelasi Nilai TSS Algoritma Parwati (2016)

Uji korelasi data lapangan TSS (Total Suspended Solid) dengan data hasil olahan TSS (Total Suspended Solid) Citra Landsat 8 menggunakan Algoritma Parwati (2006) mempunyai nilai koefisien korelasi sebesar 84 \%. Hal ini menjelaskan bahwa ada hubungan antara nilai TSS data citra dengan data In Situ sangat kuat.

\section{Analisa Perbandingan Nilai TSS Citra Landsat- 8 pada 24 Agustus 2017 dengan Data Lapangan \\ Nilai $\mathrm{R}^{2}$ yang didapat dari rumus regresi linear} menjelaskan bahwa koefisien determinasi dari data citra untuk dapat menggambarkan data di lapangan yang paling baik adalah sebesar $85,3 \%$ menggunakan algoritma Budiman. Hal ini dikarenakan algoritma Budhiman 
menggunakan kanal merah $(0,630-0,680 \mu \mathrm{m})$ sehingga perolehan nilai pada citra memiliki nilai yang paling baik. Dari hubungan ini dijelaskan bahwa sebagian besar TSS di lapangan dapat dijelaskan oleh citra. Dengan demikian nilai yang dianggap berkorelasi sedang sampai sangat kuat apabila nilai koefisien korelasi lebih dari sama dengan 0,8 atau bisa disebut korelasi sangat kuat (Sarwono, 2006). Untuk perhitungan TSS menggunakan algoritma lainnya memiliki perbedaan yang cukup menonjol antara citra dan data lapangan hal ini dapat disebabkan karena :

1. Perbedaan waktu perekaman citra dan waktu pengambilan data In Situ Waktu perekaman citra adalah Tanggal 24 Agustus 2017 pada pukul 13:03:30 (informasi ini terdapat pada meta data) sedangkan waktu pengambilan data lapangan mulai pukul 07.00-14.15 WIB. Dapat dilihat selang waktu dalam pengambilan data insitu. Hal ini dapat mengakibatkan perubahan / dinamika kondisi perairan yang mengakibatkan perubahan nilai dan sebaran TSS

2. Pengaruh radiometrik

Perbedaan nilai TSS citra dan In Situ dapat disebabkan karena pengaruh radiometrik / gangguan perambatan gelombang di udara.

\section{Analisa Status Mutu Air Dengan Metoda Indeks Pencemaran Berdasarkan Nilai TSS}

Berdasarkan nilai korelasi pada pengolahan data diatas didapatkan hubungan yang paling baik adalah algoritma Budiman, maka data hasil pengolahan data digunakan sebagai acuan data untuk menilai status mutu air dengan metoda indeks pencemaran. Melakukan analisa status mutu air dengan metoda indeks pencemaran berdasarkan nilai TSS merujuk pada Keputusan Menteri Negara Lingkungan Hidup Lingkungan Hidup Nomor 115 Tahun 2003 Tentang Pedoman Penetuan Status Mutu Air. Metode ini menggunakan model Indeks Pencemaran (IP), pada penggunaanya dibutuhkan nilai rata-rata dan nilai maksimal sampel.

\begin{tabular}{cccc}
\multicolumn{3}{c}{ Tabel 3. Nilai Analisa Status Mutu Air } \\
\hline No & Lokasi & $\begin{array}{c}\text { Indeks } \\
\text { Pencemaran } \\
\text { Data Citra } \\
(\mathrm{mg} / \mathrm{L})\end{array}$ & $\begin{array}{c}\text { Indeks } \\
\text { Pencemaran } \\
\text { Data Insitu } \\
(\mathrm{mg} / \mathrm{L})\end{array}$ \\
\hline 1 & 001 & 0,4903349 & 0,6032789 \\
2 & 002 & 0,57132 & 0,7890492 \\
3 & 003 & 0,7494797 & 0,7290321 \\
4 & 004 & $10,552,795$ & 0,5868794 \\
5 & 005 & $11,837,631$ & 0,7398683 \\
6 & 006 & 0,4178928 & 0,7368973 \\
7 & 007 & 0,3156489 & 0,4983515 \\
8 & 008 & 0,4814923 & 0,5535272 \\
9 & 009 & 0,524154 & 0,7463464 \\
10 & 010 & 0,5098771 & 0,7885205 \\
11 & 011 & 0,6383597 & 0,7964867 \\
12 & 012 & 0,6323814 & 0,913674 \\
13 & 013 & 0,5220404 & 0,7901075 \\
14 & 014 & 0,6218435 & 0,6089819 \\
15 & 015 & $13,446,251$ & $12,096,169$ \\
16 & 016 & $19,830,095$ & $12,818,674$ \\
17 & 017 & $17,236,404$ & $13,129,983$ \\
18 & 018 & $1,515,936$ & $1,122,507$ \\
19 & 019 & $14,353,703$ & $11,919,938$ \\
20 & 020 & 0,8484471 & 0,7630438 \\
\hline
\end{tabular}

Berdasarkan hasil pengolahan data untuk menentukan status mutu air dengan metoda indeks pencemaran sesuai dengan Keputusan Menteri Negara Lingkungan Hidup Nomor 115 Tahun 2003 Tentang Pedoman Penetuan Status Mutu Air didapatkan hasil rata-rata nilai berada pada rentang nilai $0 \leq$ indeks pencemaran $\leq 1$ yang berati kondisi perairan Pantai Timur Surabaya memenuhi baku mutu atau dalam kondisi baik. Beberapa titik menunjukkan nilai $1 \leq$ indeks pencemaran $\leq 5$ yang menunjukkan perairan dalam kondisi cemar ringan.

\section{Analisa Sebaran Konsentrasi TSS}

Setelah didapatkan nilai hubungan korelasi yang terbaik dan nilai analisa status mutu air, selanjutnya tersebut digunakan untuk membuat peta sebaran konsentrasi TSS tahun 2017 berdasarkan 3 alhoritma untuk menilai kondisi perairan Teluk Lamong Surabaya secara keseluruhan.

Dari Gambar 4 dapat dilihat sebaran TSS berdasarkan algoritma Laili menunjukkan kawasan pesisir memiliki kondisi nilai TSS yang tinggi dikanalingkan dengan perairan yang lebih dalam. Nilai yang tinggi bisa disebabkan karena adanya aktivitas industri dan dekat dengan pemukiman dengan banyaknya akses sungai yang menuju perairan Teluk Lamong. 


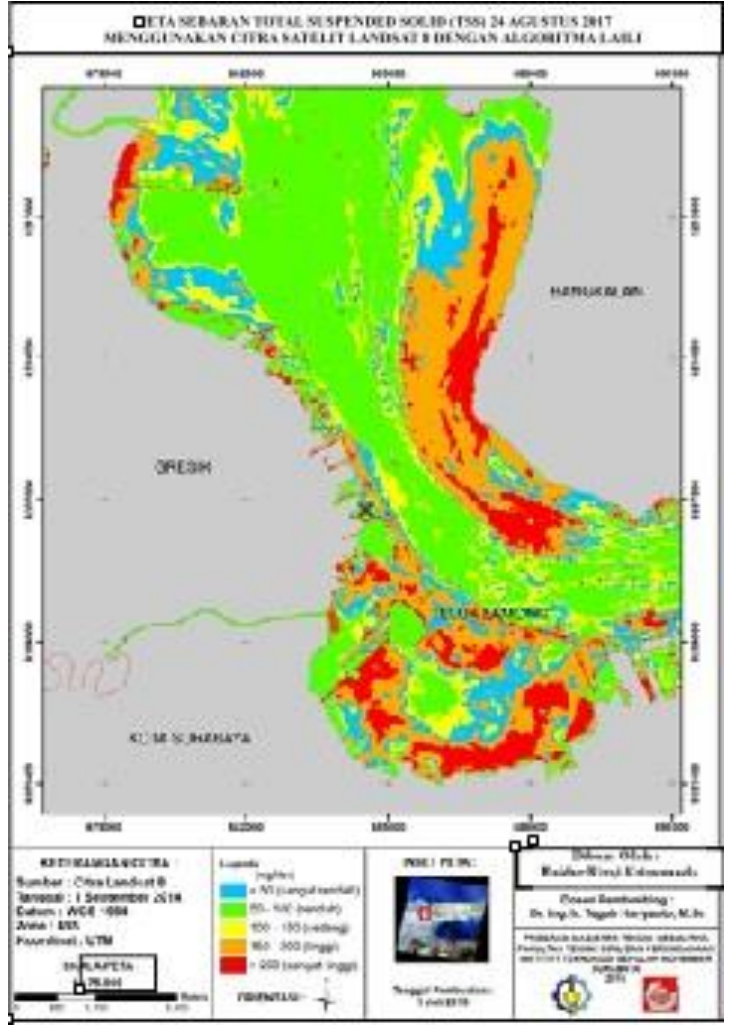

Gambar 4. Sebaran TSS Menggunakan Algoritma Laili

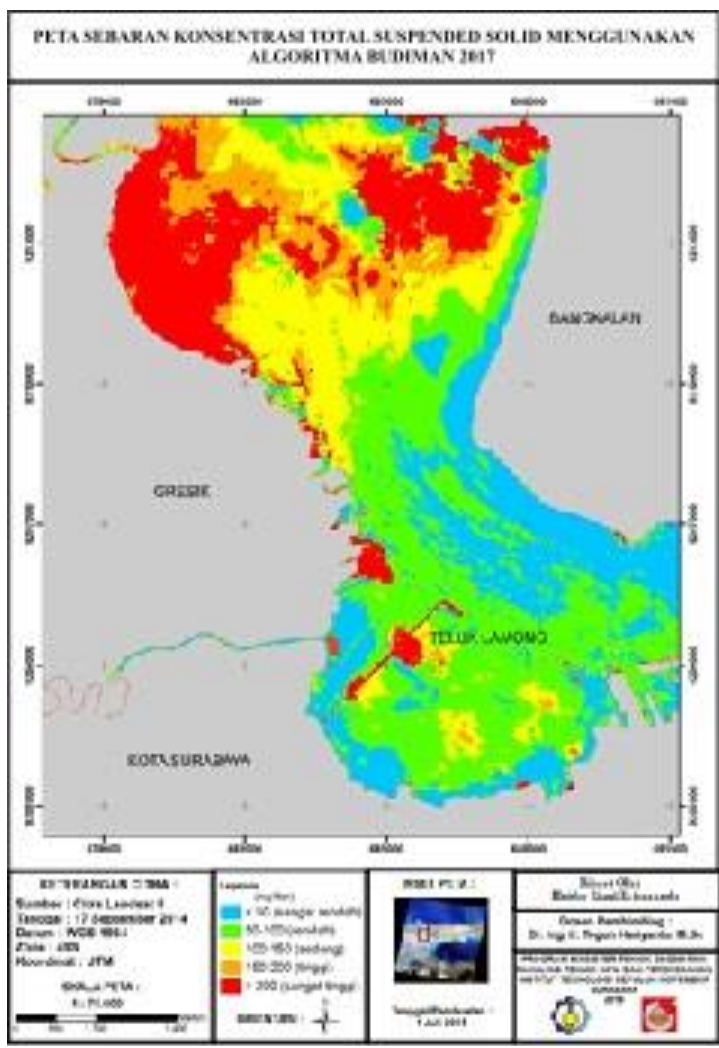

Gambar 5. Sebaran TSS Menggunakan Algoritma Budiman

Dari Gambar 5 dapat dianalisa bahwa algoritma Budiman nilai dan sebaran TSS di perairan Teluk Lamong Surabaya secara visual peta sebaran konsentrasi TSS memiliki rentang antara $1 \mathrm{mg} / \mathrm{L}$ sampai >200 mg/L, pada pesisir pantai memiliki nilai konsentrasi beragam yaitu $<50 \mathrm{mg} / \mathrm{L}$ dan ada yang $>200 \mathrm{mg} / \mathrm{L}$. Hal ini disebabkan karena di daerah penelitian adanya aktivitas industri dan dekat pemukiman dengan banyaknya akses sungai menuju perairan Teluk Lamong yang menyebabkan adanya kandungan TSS yang mencapai $>200$ $\mathrm{mg} / \mathrm{L}$.

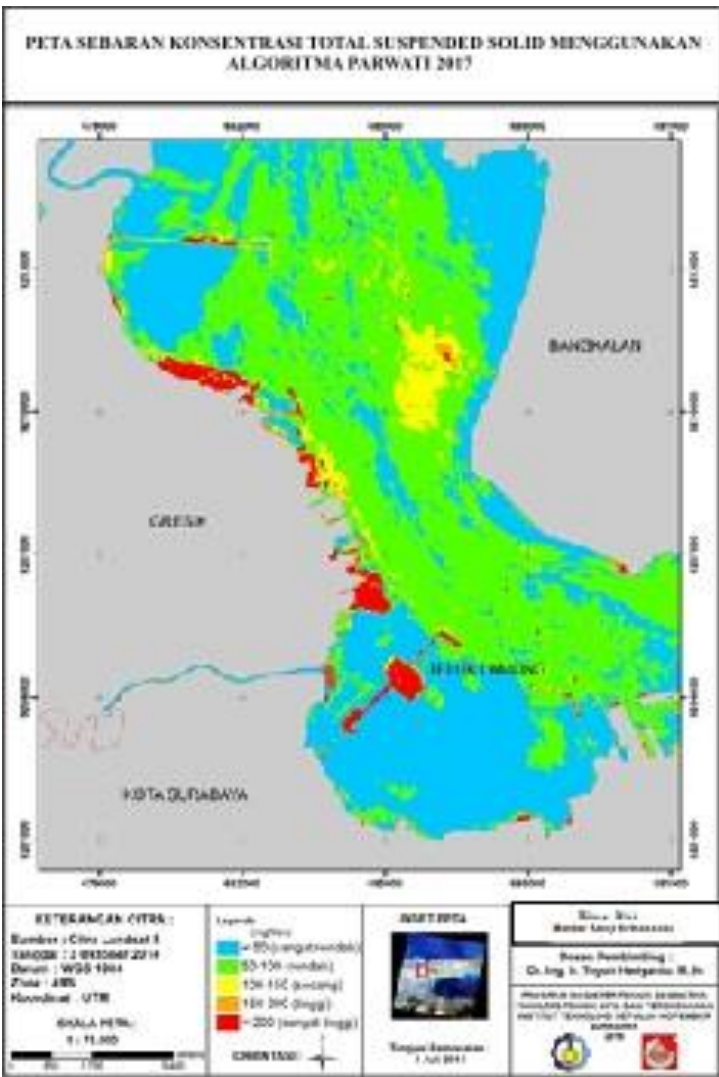

Gambar 6. Sebaran TSS Menggunakan Algoritma Parwati

Dapat dilihat pada Gambar 6 sebaran TSS berdasarkan visual peta terdapat nilai yang beragam. Namun hampir di setiap area didominasi oleh nilai kandungan TSS antara $50 \mathrm{mg} / \mathrm{L}-100 \mathrm{mg} / \mathrm{L}$ dan $100 \mathrm{mg} / \mathrm{L}-150 \mathrm{mg} / \mathrm{L}$.

\section{KESIMPULAN}

1. Dari peta sebaran TSS tahun 2014-2017 hasil pengolahan citra Landsat 8 di atas dapat dianalisa bahwa nilai TSS di Perairan Teluk Lamong Surabaya menunjukkan 
peningkatan yaitu $472 \mathrm{mg} / \mathrm{L}$ yang didapatkan dari uji laboratorium TSS menggunakan metode gravimetri. Persebaran konsentrasi TSS terjadi pada Perairan Teluk Lamong Surabaya karena kawasan tersebut dekat kawasan industri dan pemukiman dengan banyaknya akses sungai yang menuju perairan Teluk Lamong sehingga ada banyak material TSS yang terkonsentrasi di daerah tersebut.

2. Kondisi sebaran TSS pada perairan Perairan Teluk Lamong Surabaya sejak tahun 2014 sampai tahun 2017 mengalami perubahan setiap tahun. Perubahan terjadi karena faktor alam dan perkembangan aktivitas manusia. Kondisi perairan idealnya harus memiliki $\leq 80 \mathrm{mg} / \mathrm{L}$ kadar Total Suspended Solid sebagai syarat bahan baku untuk keperluan air bersih.

3. Uji korelasi data lapangan TSS (Total Suspended Solid) dengan data hasil olahan TSS Citra Landsat 8 tahun 2017 pada tanggal 17 Maret 2017 menggunakan algoritma Syarif Budiman (2004) Sebesar 85,3\%, algoritma Parwati (2006) sebesar $84,1 \%$, algoritma Laili (2015) sebesar 82,6 $\%$. Penggunaan citra satelit Landsat 8 pada penelitian konsentrasi nilai TSS pada tahun 2014 hingga 2017 ini menghasilkan nilai $\mathrm{R}^{2}$ paling baik dihasilkan dengan menggunakan algoritma Budiman (2004), menghasilkan koefisien determinasi sebesar $85,3 \%$. Nilai koefiseien determinasi yang mendekati satu atau $100 \%$ menunjukkan hubungan yang positif, sebaliknya jika $R^{2}$ mendekati nol, maka memiliki hubungan jelek. Dengan demikian citra Landsat 8 dapat digunakan untuk menggambarkan kondisi Perairan Teluk Lamong Surabaya seperti pada kondisi yang ada di lapangan.

Berdasarkan hasil kesimpulan penelitian ini yang telah di jelaskan, adapun saran yang diberikan penulis:

1. Penggunaan algoritma perhitungan TSS harus sesuai atau mendekati dengan nilai korelasi yang terbaik, hal ini berkaitan erat antara hasil citra dan hasil In Situ

2. Pengambilan data In Situ sebaiknya dilakukan pada tanggal atau waktu yang sama dengan akuisisi data citra yang akan digunakan

3. Perlu perhatian dan penanganan khusus dalam masalah TSS ini karena jika dibiarkan terus menerus akan menghasilkan dampak pencemaran perairan Teluk Lamong Surabaya

\section{UCAPAN TERIMA KASIH}

Penulis H.R.K. mengucapkan terima kasih kepada Bapak Dr. Ing. Ir. Teguh Haryanto, M.Sc. selaku dosen pembimbing yang telah memberikan bimbingan dan dukungan, baik moril maupun materil dalam penelitian ini.

\section{DAFTAR PUSTAKA}

Siagian, L. 2008. Analisis Tingkat Pencemaran Logam Berat Perairan Laut Belawan. Medan. Lembaga Penelitian Universitas Nommensen.

Wijaya, U \&Kartika, C. 2004. Kombinasi Lumpur Aktif-Membran Untuk Pengolahan Air Limbah Domestik. Surabaya. Tugas Akhir Jurusan Teknik Kimia ITS.

Saeni, M. S. 2008. Biologi Air Limbah. Bogor: Program Pasca Sarjana IPB.

Effendi, H. (2003). Telaah Kualitas Air Bagi Pengelolaan Sumberdaya dan Lingkungan Perairan.Yogyakarta: Kanisius.

Lestari, I. B. 2009. 'Pendugaan Konsentrasi Total Suspended Solid (TSS) dan Transparansi Perairan Teluk Jakarta dengan Citra Satelit Landsat'. Skripsi. Bogor: Institut Pertanian Bogor

USGS. 2013. <URL: http://Landsat.usgs.gov/band des> Dikunjungi tanggal 3 Januari 2017, jam 10.22

Abidin, H,Z. 2002. Survei dengan GPS. Jakarta: Padnya Paramita.

Vermote, F, dkk.1997. "Second Simulation of the Sensor Signal in the Sensor SpectrumVector, 6S: an overview', IEEE Trans. Geoscience. Remote Sensing., vol. 35 no. 3, pp-675-686, May 1997.

Gao, B. 1996. “NDWI-A normalized difference water index for remote sensing of vegetation liquid water from space," Remote Sensing Environment., vol. 58, no.3, pp. 257-266.

Budhiman, S, 2004. Mapping TSM Concentrations From Multi Sensor Satellite Images in Turbid Tropical Coastal Waters of Mahakam Delta Indonesia, Enschede: MSc Thesis ITC Enschede, The Netherlands. 
Parwati, E. Tatik Kartika, Sri Harini, Fany Diah K. Pemodelan Dinamika Spasial Pengelolaan Lahan Pesisir Kabupaten Berau, Kalimantan Timur Menggunakan Data Inderaja. 2006. Laporan Akhir Riset Unggulan Kemandirian Kedirgantaran LAPAN

Laili, L. J. 2015 . Development Of Water Quality Parameter Retrieval Algorithms For Estimating Total Suspended Solids And Chlorophyll-A Concentration Using Landsat-8 Imagery At Poteran Island Water. 55-62.

Sarwono, J. 2006. Metode Penelitian Kuantitatif dan Kualitatif. Yogyakarta :Graha IImu. 